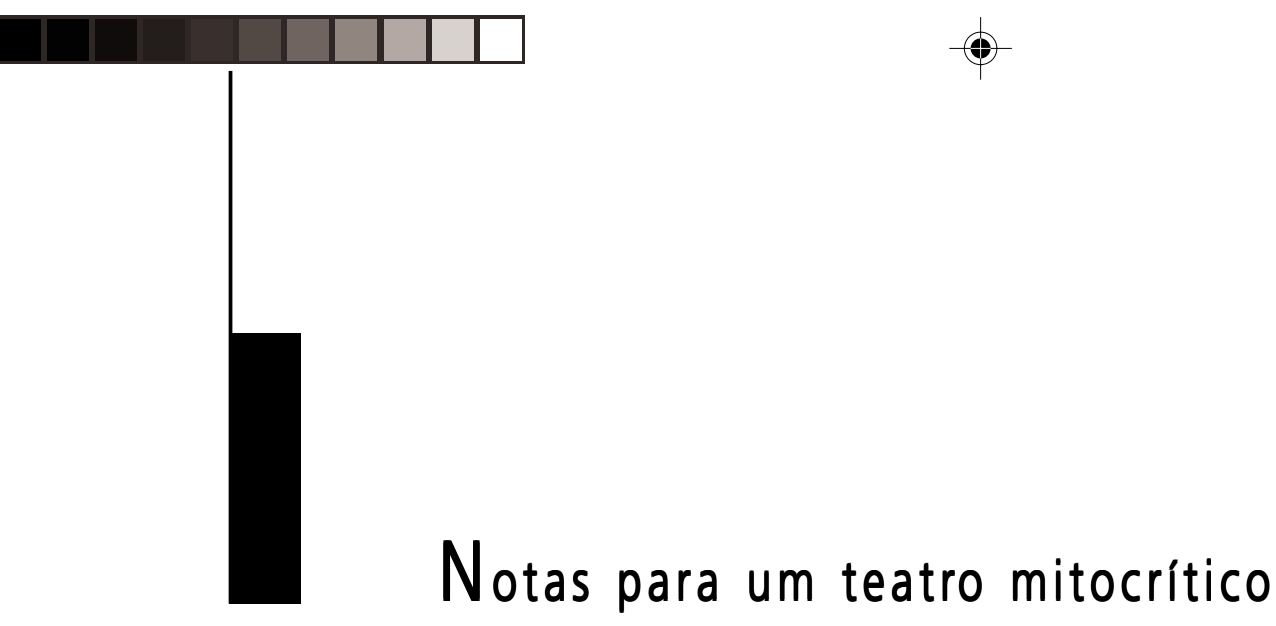

Armando Nascimento Rosa

"As afinidades compulsivas entre a forma filosófica e a forma poética, o seu nascimento geminado no impulso primordial em direção ao significado, em direção à tentativa da consciência humana de encontrar alojamento no mundo conhecido - tentativa a que podemos chamar "mito" - provocaram esses conflitos de que a República de Platão continua a ser um exemplo" (George Steiner, Paixão Intacta).

\section{A psique é mitodramática}

al como o sonho para Freud, na sua centenária teoria da interpretação dos sonhos, também para mim a escrita de uma peça teatral tem por base um desejo primordial: o desejo de ver a transformação daquele guião de palavras e ideias com potenciais imagens num espetáculo de gente viva e atuante no lugar da cena. Mas esse desejo, que preside à escrita do sonho de acordados que o teatro é, consiste num desejo explícito, cuja latência é inteiramente manifesta, contrariando freudianas censuras, mesmo sabendo que a raiz desse desejo tem uma natureza que se estende por uma vasta paisagem que os olhos da consciência já não alcançam, mas apenas intuem.
Com estes mesmos olhos da consciência dirigidos para o que faço, tanto na escrita dramática como nas incursōes do ensaio (tendo o teatro por horizonte), verifico que uma designação me será comum a ambas estas modalidades de produção estética e hermenêutica: refiro-me a uma constante mitocrítica, dinamizadora simultânea de imaginário e pensamento.

Que é isso de teatro mitocrítico? É a pergunta que coloco a mim mesmo no arranque deste artigo. Começo pelo termo mitocrítico. Ele ocorre-me num exercício de imaginação conceptual, não obstante estar ciente do contexto semântico e metodológico influente com que Gilbert Durand cunhou o termo, a partir dos anos 70 do século passado. Mas confesso que me interessa agora antes de mais perseguir o sentido que a etimologia desta palavra composta me suscita. Mitocrítico pareceu-me à partida uma expressão capaz de reunir e conciliar operativamente as duas facções da querela antiga que Platão instituiu, já bem patente no Íon, entre filósofos e poetas: sendo que o mito se encontra do lado da poesia; e a crítica é o ofício reflexivo da filosofia que pode, se a tal se dispuser, intentar uma perspectiva interpretativa do "delírio mítico" do poeta-xamã. Renunciando à radicalização do seu mestre, que expulsava os

Armando Nascimento Rosa é dramaturgo, ensaísta e professor adjunto na Escola Superior de Teatro e Cinema do Instituto Politécnico de Lisboa. 
poetas da cidade ideal, Aristóteles identifica um lugar discursivo de meio termo onde se fundem poesia e filosofia num casamento inesperado: nos três gêneros teatrais cultivados pelos gregos (tragédia, comédia e drama satírico), a criação dramática configura o terceiro termo que proporciona uma síntese para a antítese platônica entre poesia e filosofia. Porque é conveniente não esquecer que o alvo de estudo da Poética esse que ficou sendo conhecido como o primeiro tratado de teoria literária no Ocidente - é precisamente a poesia dramática e a destinação cênica a que esta está votada. Na Poética, surpreende-nos Aristóteles ao afirmar que a Poesia dramática é algo mais filosófico do que a História porque, ao contrário dos particularismos factuais desta, o drama visa a representação do universal através dos caracteres que integram a ação teatralizada. Esta declaração, que decerto faria estremecer Platão, seu mestre, é uma tomada de posição que legitima por inteiro a abordagem mitocrítica vista nestes moldes, uma vez que reconhece uma vocação filosófica nos modos com que o dramaturgo concebe os mitos para serem expostos no palco da pólis. E é o mesmo Aristóteles que fala do mito como alma do drama, ainda que a acepção aristotélica de mito, na Poética, seja eminentemente secular, mais abstrata (ou conceptual) do que sincrética, e se reporte ao que entendemos por estória, enredo, narrativa que a cena dramatiza. Esse mito de que fala o filósofo não é necessariamente a matéria prima elementar dos sistemas de crença religiosa, embora possa com ela coincidir, visto que os mitos a que o teatro antigo recorre pertencem ao universo politeísta e xamânico, onde deuses e seus poderes ou influências contracenam com personagens objetivamente mortais, que só o teatro dotará de imortalidade simbólica. Esta ambiguidade está por isso inerente às origens do teatro e ao pensamento sobre ele no Ocidente; ou seja, os mitos gregos que motivam a criação dramática emergem de dois afluentes distintos, mas oriundos porém de um rio comum: o afluente numinoso e xamânico das mitologias que alimentam o sentido e a forma dos rituais e das mundividências que lhes estão associadas; e o afluente poético-narrativo que está na base da autonomia artística dessa atividade humana a que o futuro chamará literatura.

A sobrevivência do mito no secularismo estético das literaturas nem sempre é tão estritamente secular, como é sabido, visto que servirá, muitas vezes, para disfarçar credos heréticos ou simplesmente incômodos (porque socialmente minoritários e/ou reprováveis pelos poderes dominantes), sob os figurinos aparentemente inócuos da efabulação literária. No teatro, esta aparência inócua tende obviamente a desfazer a sua camuflagem, exibindo em pleno os alvos a que se destina, não obstante o despiste irônico e lúdico de sentidos que a cena produz no espectador. Num outro ângulo, também a literatura e a arte dramáticas, portadoras do vinculo numinoso das suas origens (e digo numinoso na acepção etimológica do termo, visto que os numes ou daimónes eram humanamente invocados para a aparição no rito lúdico da cena), darão à luz novos complexos míticos, pela vias geminadas da imagética, da narrativa e da ação. Complexos esses que se constituem como verdadeiros atratores da psique, conjurados pela imaginação poética, a que Bachelard chamou complexos de cultura, ao identificar exemplos deles - como sejam o complexo de Ofélia ou o complexo de Swinburne (em $A$ Água e os Sonhos, 1942).

A partir do último quartel do séc. XIX, dá-se, em metamorfose, um retorno afirmativo do mito, esse recalcado na utopia unilateral que dominou o racionalismo moderno. $\mathrm{O}$ seu regresso aloja-se num centro nevrálgico do sujeito da cultura, difícil já de extirpar a partir daí; refiro-me à manifestação dos recursos mitológicos mobilizados pela psicologia do inconsciente, que fornecem modelos de explicabilidade a uma possível hermenêutica da psique o contributo de Nietzsche é também sintomático e significativo do regresso da imaginação mítica como expressão do recalcado no discurso filosófico do Ocidente, com toda a (psico)patologia inerente à violência do seu gesto. 
Os mitos psicanalisam-nos na nossa tentativa mesma de os psicanalisar. Eles falam da pluralidade dramática da psique porque é neles que a psique exprime a geografia profunda $\mathrm{da}$ sua linguagem. Isto porque a psique humana possui uma natureza mitodramática, a começar pela palavra grega que a nomeia, sinônima do nome da jovem mortal Psique que contrai núpcias, sem o saber, com o deus Eros, esse estranho amante que não quer deixar-se ver por ela à luz do dia. Uma atividade mitocrítica pode ver-se transfigurada na narrativa aventurosa deste casal singular a que Apuleio deu forma literária: se aceitarmos que Eros representa a função complexa inscrita na misteriosa sedução do mito; e Psique, por sua vez, representará o desejo "crítico" da consciência que pretende conhecer o mistério dessa atração de acordo com as várias dimensões que a experiência humana proporciona. Pela observação dos trabalhos árduos em que a humana Psique se vê implicada, percebe-se como o envolvimento íntimo com a natureza poderosa do mito se pode tornar em motivo de sobrevivência ou aniquilação do humano. Nos conteúdos de um "nada que é tudo", segundo a definição pessoana de mito, reside um brilho fascinante e perigoso, encantatório mortífero, belo e abissal; como bem o sabemos ao vivenciar o terror e a compaixão que o espetáculo interativo da História produz em nós, nesta dupla condição de agentes e pacientes dela. E o mito é tema multiforme que passa a pulsar na circulação cultural da modernidade tardia, com Freud e com Jung a incentivar-nos para empreender diferentes mitanálises dela.

Não é espaço e lugar aqui para teorizar sobre o mito enquanto polarizador de discussões no consciente coletivo; e bem assim aos modos de entendê-lo nas suas múltiplas acepções, antiga, moderna, contemporânea. Mas da intenção em procurar extrair sentidos e leituras de constelações míticas, habita a pulsão mitocrítica que resulta, como o nome indica, da aliança entre a fonte magnética e esfíngica do mito e a vontade hermenêutica de saber o que ele diz, o que ele é capaz de nos fazer ver e dizer e que de outro modo não poderíamos exprimir. Como o mito foi para os antigos matéria de inspiração criativa, o enamoramento que a psicologia profunda fará com o imaginário mitológico, para que a psique possa falar de si própria, manifesta uma força motriz desafiadora da imaginação simbólica na arte.

\section{Uma vocação mitocrítica}

A pulsão que me conduz à criação dramatúrgica descobre a sua dimensão mitocrítica neste jogo entre o mito como motor da imaginação dramática e a imaginação dramática como potenciadora de sentidos que reconhecem na psique humana a natureza simbólica do discurso mítico. $\mathrm{O}$ teatro e a dramaturgia são dinamizados por materiais mitológicos desde as suas origens, de maneiras mais ou menos explícitas. E talvez seja apenas uma simples tautologia reclamar a legitimidade da designação de teatro mitocrítico. Persisto porém em fazê-lo, uma vez que clarifica para mim o que me traz na paixão pela escrita para cena, desde a minha primeira peça, concluída em 1988, na qual um motivo mítico me servia para transformar em teatro o terror e a compaixão que experienciei perante uma tragédia contemporânea assistida à distância, através da mídia: o desastre nuclear ocorrido na cidade de Goiânia, em 1987, e que daria origem a Goiânia - Uma Nova Caixa de Pandora, obra dramaturgicamente ambiciosa que pretendia, na experimentação juvenil da minha escrita para teatro, aferir a possibilidade de abordar em teatro o trágico da condição contemporânea, de habitantes num planeta vivo com futuro ameaçado.

Numa conferência que proferiu em 2006, em Nova Iorque, acerca da obra dramática que venho laborando, António Mercado destacaria algo que foi iluminante para mim, face ao lugar criativo em que me movo. Dizia Mercado que a singularidade deste lugar advinha do fato de eu não ter partido para o teatro como alguém prioritariamente proveniente do universo da litera- 
tura, mas antes da filosofia, e que entretanto aliei esta última à proximidade prática com a cena teatral propriamente dita, num confronto constante com a teorização crítica dela. Vejo assim a experiência mitocrítica acontecer, neste caso, quando a simbiose se dá entre a cena teatral (o espaço do mito enquanto ação poética) e a indagação filosófica (numa reflexão crítica que se dirige para o lugar cênico, ritualístico e produtor de sentidos). Na compreensão que traço do que entendo por mitocrítico, é como se o poético do mito se revelasse amplificado pela ritualidade profana, política (porque se destina à pólis) e inventiva da cena teatral. A poesia da palavra dramática amplia-se, expande-se e impregna-se por essa poesia outra não verbal que habita o evento cênico, num rito partilhado que torna o verbo mais intenso e comunicante. De fato, algo deste teor sucedeu comigo na mitologia pessoal do vivido, despoletando a consciência de uma vocação, que considero oportuno evocar aqui.

Em Setembro de 1987, era eu finalista da graduação em filosofia na Universidade Nova de Lisboa, assisti a um espetáculo que me impressionou fortemente. Já não sei o que levou a minha distraída teatrofilia de então ao espaço que era ainda ocupado pelas ruínas do antigo e imponente Theatro do Gymnásio (pouco depois infelizmente alienado para centro comercial). Não sabia quem era o encenador, nem sequer o grupo, e fruí o impacto como atônito neófito. $\mathrm{O}$ interior esventrado do teatro, pela devastação de um fogo que o consumira décadas antes, era só por si um cenário potenciador do Calderón, de Pier Paolo Pasolini; uma peça de feição e intertextualidade barrocas, que trazia à luz visível da metáfora crua as memórias traumáticas da Europa do pós-guerra, registradas no eco íntimo e demencial de uma família burguesa, aracnídea, ou nos reversos exasperados de um certo idealismo existencial que identificamos com a década de sessenta, tempo de escrita da peça. Retive o turbilhão psico-político e o lirismo noturno do Calderón pasoliniano naquela generosidade evidente dos atores, habitantes de um espaço manifestamente hostil, que eles transformavam num palco humano e magnífico (lembro-me de dar por mim a pensar, dias depois, onde teriam eles camarins naquela desolada ruína). Nem me dera conta, enquanto espectador, de que aquele corifeu, alter ego autoral, que lia para nós, sentado algures atrás do público, era o próprio encenador do espetáculo, que eu não conhecia então: Mário Feliciano (1951-1995), o discípulo português de Luca Ronconi, com quem eu viria pela primeira vez a trabalhar em teatro, como dramaturgista, a partir de 1990, nas suas últimas criaçōes profissionais. Ao sair lembro-me só de uma convicção que me tomou: o que eu queria a partir daí era escrever teatro; aquela era em definitivo a mais desafiadora das formas de escrita, precisamente porque não se esgotava no processo $\mathrm{da}$ leitura comum, e podia revestir-se de um caráter psico-activante do qual eu acabava de ser uma testemunha cúmplice. Ao Mário Feliciano, ao verbo poético-cênico de Pasolini, e àqueles atores num teatro que parecia ter as marcas físicas de uma destruição deixada pela guerra, devo o despertar dessa centelha que logo a seguir produziria em mim Goiânia-Uma Nova Caixa de Pandora; peça inédita nunca representada, que necessitava de mais de vinte atores, e que a Comuna-Teatro de Pesquisa (companhia onde eu faria a minha estreia cênica doze anos depois) distinguiria com uma menção honrosa no Premio Alves Redol, de instituição única, nesse ano de 1988.

Vinte e um anos transcorridos, e graças à visibilidade cênica que tem conquistado por si própria desde 2000, a dramaturgia que escrevo tem procurado contrariar as fatalidades comuns que envolvem o desencontro entre a escrita dramática portuguesa e a realização teatral dela. Um desencontro que possui raízes fundas em censuras seculares que desfiguraram a possibilidade do teatro português em adquirir uma identidade e tradição dramatúrgicas: primeiro com a Inquisição que asfixiou a herança viva do legado vicentino, durante três séculos; mais recentemente, com a ditadura salazarista que, entre 
muitas outras consequências nefastas, aniquilou a manutenção de uma ligação produtiva entre a criação escrita mais arrojada e a prática teatral durante meio século, em Portugal; feridas fundas cujas marcas permanecem visíveis na psique coletiva, como o filósofo José Gil o diagnosticou exemplarmente no livro Portugal hoje, o medo de existir (2004). Não desejo porém demorar-me agora neste assunto, deceptivo mas necessário, que daria por si só matéria para dissertaçôes acadêmicas.

Regresso à vocação mitocrítica que descubro no meu teatro escrito, ao identificar diversos modos de trabalhar materiais mitodramáticos. Numa rápida distribuição segundo o enfoque temático, sem me deter em considerações de conteúdo (que o leitor encontrará analisadas no estudo $O$ Verbo da memória, que Ana Maria Bulhões dedica à minha dramaturgia), parece-me plausível reunir do seguinte modo o conjunto de obras dramáticas que produzi até esta data:

a) revisitação e reescrita de mitos helênicos e/ ou judaico-cristãos: Um Édipo - O drama ocultado (2003); Maria de Magdala - fábula gnóstica (2005); Nória e Prometeu - Palavras do fogo (2004); e Antígona Gelada (2008).

b) personagens e/ou enredos de proveniência histórica e literária: A última lição de Hipátia (2004); A Ilha de Colombo (inédito, data de escrita: 2005); O Eunuco de Inês de Castro Teatro no pais dos mortos (2006); As duas mulheres de Sigmund Freud - libreto de ópera cur- ta (2008); Visita na Prisão ou O último sermão de António Vieira - ficção histórico-cênica (2009); O Sonho de Rosa Damasceno ou Públia Hortênsia, marinheira estática (inédito, data de escrita: 2009).

c) temas de mitografia poética, literária e teatral: Audição - Com Daisy ao vivo no Odre Marítimo (2002); A Ilusão Cósmica - Viagem ao futuro no palco (2005); Cabaré de Ofélia (2007); Não és Beckett, não és nada, ou Espera apócrifa reloaded (1990, 1999, 2009); Os mortos viajam de metro - libreto de ópera com prelúdio em ato único (data de estreia: 2010).

d) fábulas de ambiência contemporânea onde elementos históricos e míticos se disseminam na ação: Goiânia - Uma nova caixa de Pandora (inédito, data de escrita: 1988); Vozes invasoras - uma comédia de horrores sobre os direitos humanos (estreia parcial: 2001); Lianor no país sem pilhas (2000); O Túnel dos ratos (2004); Lianor e a boneca chinesa (inédito, data de escrita: 2009).

\section{0 que é teatro gnóstico: ensaiar uma tipologia mitocrítica}

Ainda que só no posfácio ${ }^{1}$ à edição norte-americana de Um Édipo - O drama ocultado, trace pela primeira vez com mais detalhe um retrato conceptual do que entendo por teatro gnóstico, esta designação cedo me surgiu associada à dramaturgia que concebo. Comecei de fato a

Este ponto 3 resulta de uma revisão e ampliação de um excerto deste posfácio (intitulado An Oedipus The untold story: A Gnostic drama under the sign of Hermes), numa tradução de Carlos Machado Acabado, visto que o redigi originalmente em inglês para ser apresentado como conferência em 9 de Julho de 2005 nos EUA, na A \& M University of Texas, na 2nd Academic Conference of Analytical Psychology and Jungian Studies, a convite da International Association for Jungian Studies. A versão anterior do excerto, traduzido por Carlos Machado Acabado, foi originalmente publicado online com o título "O que é o teatro gnóstico. Breve introdução a um conceito dramatúrgico” na revista electrónica Verónica (no 1, 2008, pp. 16-19), da Escola Superior de Teatro e Cinema do Instituto Politécnico de Lisboa (http://veronica.estc.ipl.pt). 
problematizá-la, em letra publicada, quando da minha estreia cênica como dramaturgo em 2000, aplicando-a a uma leitura (mitocrítica) da peça Lianor no País Sem Pilhas, estreada no Centro Cultural de Belém, em Lisboa, numa coprodução com a Comuna-Teatro de Pesquisa, encenada pelo seu diretor artístico, João Mota, discípulo português de Peter Brook.

Ao associar o que laboro à designação de teatro gnóstico, um exercício de imaginação mitocrítica está presente no resgate a um termo que exprime por si só o recalcado por excelência ao longo do tempo histórico. $\mathrm{O}$ teatro como ato de conhecimento expressa-se na etimologia da palavra grega gnosis; um conhecimento míticofilosófico que nasce com a era cristã e que nos primeiros séculos desta é perseguido e dizimado pela ortodoxia religiosa triunfante, convertendose em rio subterrâneo, espécie de inconsciente que irriga e nutre o marginalizado pela tradição dominante na civilização ocidental. A multiforme cosmovisão gnóstica mostra-se rebelde e avessa a submissões dogmáticas e procede pela faculdade da imaginação, como se esta fosse uma revelação sempre atualizada no processo da experiência existencial do humano; e daí, por exemplo, o estudo já clássico de Hans Jonas ter aproximado motivos do gnosticismo antigo com formas de existencialismo novecentista.

Há muito que o termo gnóstico começou a ganhar sentido para mim, em especial sob o influxo da heterodoxia contagiante de Fernando Pessoa. Tenho porém consciência da equivocidade que a sua aplicação pode provocar, em virtude dos usos, ora nebulosos ora paradoxais, que a (já por si herética) designação gnóstico tem conhecido e conhece atualmente. Basta fazer uma breve viagem pela internet para o confirmar. Se por um lado encontramos o termo gnóstico a servir de senha mal-fundamentada para designar organizaçōes pseudo-esotéricas que ofendem a inteligência (e excluo deste lote um Stephen Hoeller e uma Rosamonde Miller, dada a seriedade intelectual que sustenta os seus respectivos ministérios), por outro, mesmo na esfera das Humanidades, é motivo para abordagens que o deformam irreversivelmente. Exemplo mais representativo disto é a interpretação feita pelo politólogo Eric Voegelin que, ao distender de forma aberrante o alcance do termo gnóstico, o esvazia, tornando-o irreconhecível.

Devo afirmar que a valorização e o destaque de que o gnosticismo é alvo no pensamento psicológico de Jung me ajudou bastante a não desistir do termo, além de que me permitiu um quadro de entendimento teórico aplicável ao domínio das estéticas teatrais. Nesta linha, entendo por gnóstico, em sentido lato, a predisposição a um estado de abertura criativa e crítica que concebe o domínio específico da psique individual como um lugar privilegiado de onde podemos aceder a um mais vasto universo de conteúdos arquetípicos que transcendem o inconsciente individual e o plano estritamente pessoal ou biográfico; ou seja, aquele espaço de sentido que Jung nomeou por inconsciente coletivo.

O conceito de teatro gnóstico exige, a meu ver, uma abordagem crítica ulterior mais demorada, até porque a reverberação nele produzida pelas mundividências mítico-filosóficas do gnosticismo introduz elementos irradiantes que merecem particular atenção, nomeadamente no que respeita às noçóes do mal e do tempo, que são centrais a uma compreensão do drama, em especial do drama trágico. Permito-me a uma auto-citação, da introdução do meu estudo extenso sobre o teatro de António Patrício, onde afloro a importância mitocrítica desta dupla formada pelo mal e pelo tempo; "uma parelha conceptual que intriga o filósofo e que no drama não se resume a dois conceitos em abstrata neutralidade, revestindo antes o perfil de enigmas gnósticos." O mal e o tempo "constroem todo e qualquer entrecho trágico. O tempo, nosso único percurso, não é só por si um mal, mas é ele a condição de possibilidade para que o mal se manifeste; o drama, mimese da vida, é duração, mudança, revelação, e corruptibilidade" (Rosa, 2003, p. 49).

Mas na síntese possível do presente artigo, desejo apenas fornecer uma espécie de brevíssimo relance introdutório ao tentar com- 
preender o teatro gnóstico no contexto mais amplo da tradição teatral do Ocidente.

Para já, convém distinguir diferentes formas de expressão teatral, ainda que, em termos práticos, tais formas de expressão nos surjam frequentemente fundidas ou combinadas de modo estreito e estruturante entre si. É, com efeito, extremamente raro e pouco provável que encontremos essas formas teatrais, digamos assim, em estado puro, tanto nas gramáticas e partituras de cena (veja-se o caso de Meyerhold, cujo nomadismo experimentalista exponencia diferentes modalidades consoante a etapa criativa em que se encontra), quanto nos textos dramáticos escritos.

Importa reconhecer para já cada uma dessas categorias a que aludo, passíveis de identificação no universo do teatro em geral. Constato a existência de quatro categorias distintas. Trata-se aqui, como em todas as incursões tipológicas no âmbito estético, de uma quaternidade com contornos de mandala teórica, susceptível, por isso, de desvanecer-se a todo o momento, mercê de mudança de ângulo ou perspectiva de observação. Ao tentar desenvolver esta taxonomia teatral tetramórfica, dei-me conta de haver nela uma correspondência plausível com o modelo das quatro funções psicológicas, enunciadas por Jung na sua tipologia da consciência.

Sem ter a veleidade de uma enunciação exaustiva de características definidoras e de fontes teóricas que as alicerçam, apresento estas quatro formas de expressão teatral no intuito de que elas possam servir de mapa que permita tornar discernível o caminho conducente à noção de teatro gnóstico.

(1) Teatro Dramático: o teatro que se baseia na ideia de identificação emocional, entre o espectador e aquilo que ocorre em cena. $\mathrm{O}$ objetivo desta forma teatral é a catarse através da empatia; algo que é atingido por intermédio de uma estética eminentemente realista. $\mathrm{O}$ teatro dramático apresenta experiências de vida aos espectadores. Fá-lo com um tal grau de verossi- milhança, que estes são facilmente levados a projetar-se espontaneamente nas interaçōes psicofísicas que têm lugar no palco. Esta identificação com os caracteres do drama conduz, em última instância, à libertação de tensões/energias emocionais durante a representação cênica.

De entre as quatro formas teatrais, o teatro dramático envolve a mais direta modalidade de mimese do vivido, tal como ela é experienciada a um nível mais comum, e por isso constitui a base primordial para todas as outras formas subsequentes de expressão teatral.

Dois patronos míticos proponho para o teatro dramático: Dioniso, esse deus turbulento da máscara e do êxtase imanente que detém a tutela simbólica da tradição teatral no Ocidente; e Eros, que personifica a energia dinamizadora do (des)encontro passional entre seres, geradora do drama como (inter)ação (já que drama significa, etimologicamente, ação). As fontes teóricas capitais do teatro dramático remetem, em primeiro lugar, para Aristóteles, o fundador da estética teatral ocidental; e para Stanislavski, o criador do "sistema" de representação teatral baseado num realismo psicológico interno. Stanislavski teve, como é sabido, diversos "continuadores" norte-americanos, entre os mais influentes dos quais se contam: Lee Strasberg, um ex-aluno de Boleslavski, que enfatizou no seu famoso "Método" a concepção de homo neuroticus oriunda de Freud; e Stella Adler, uma discípula da técnica das açôes físicas de Stanislavski - ambas estas metodologias, ainda que diversas entre si, deixaram uma marca indelével, não apenas no teatro, mas sobretudo na representação do ator em cinema.

Para usar uma analogia antropomórfica, o teatro dramático é o teatro como alma, enquanto sede das paixôes humanas, o lugar onde o mistério da vida é revelado pelo re-viver dessa mesma vida sob o simulacro da representação cênica.

Em termos de tipologia junguiana, o teatro dramático opera radicado na função sentimento (feeling function) proposta por Jung. 
(2) Teatro Crítico: o teatro que assenta numa abordagem cognitiva da realidade. Os seus objetivos são de ordem prioritariamente racional; e daí a procura por distanciar-se da empatia emocional e da catarse através do recurso a estratégias de narratividade e a dispositivos intencionalmente não-dramáticos. $\mathrm{O}$ teatro crítico usa a ironia e a alegoria como instrumentos estilísticos, de natureza expressiva, destinados a provocar no espectador um compromisso deste com os conteúdos intelectuais do discurso cênico. $\mathrm{O}$ alvo central desta forma teatral é o apelo às faculdades críticas de cada espectador, enquanto participante ativo de uma sociedade. Deste modo, as questôes políticas são o fulcro das preocupaçôes do teatro crítico, que não se inibe de assumir posições de natureza ideológica, com uma apetência pelo registro didático.

A tutela mítica do teatro crítico pertence a Atena, a deusa estratega da razão; se bem que do perfil combativo desta forma teatral não está ausente a sombra do bélico Ares. As fontes teóricas mais influentes do teatro crítico são Platão (enquanto feroz opositor do teatro trágico, defendendo em vez disso um teatro que ensine o intelecto ao invés de excitar as paixôes irracionais); Erwin Piscator, fundador do Teatro Épico, uma estética fortemente socio-política que viria em seguida a ser largamente desenvolvida, com alicerces (anti) aristotélicos, por Bertolt Brecht; e os ensaios de Walter Benjamin sobre o assunto, por este escritos após a publicação do seu estudo fundamental sobre as origens do trauerspiel (drama lutuoso). Na filiação direta do teatro político, o Teatro do Oprimido de Augusto Boal, motivado que foi pela pedagogia de Paulo Freire, é uma manifestação de teatro crítico que subverte, com propósitos intencionais, mecanismos da relação convencional entre ator e espectador. Retomando a analogia antropomórfica atrás sugerida, o teatro crítico é o teatro como mente, o domínio das ideias, do significado, e da linguagem, no qual podemos forjar sentidos para o mundo empírico em que estamos.
Em termos junguianos, o teatro crítico encontra a sua analogia na função pensamento (thinking function) proposta por Jung.

(3) Teatro Cenoplástico: o teatro fundado no encantamento dos sentidos; nos prazeres cênicos da vista, assim como na experiência extática proporcionada pelos outros modos de percepção humana. O teatro cenoplástico emerge fundamentalmente a partir da concepção espacial, da estética sonora, do ritmo e da luz, da aparição e da ausência, da música e do silêncio. Pode, eventualmente, renunciar por inteiro à palavra falada e aproximar-se da escultura e da pintura, da dança e da música. Para o teatro cenoplástico, a experiência teatral é um evento performativo orgânico ou disruptivo, não necessariamente dramático, que pode tomar a forma de uma sequência de imagens oníricas (isto é, análogas à lógica do sonho). O teatro cenoplástico recolhe a sua inspiração do significado contido na etimologia do vocábulo grego designativo de "teatro": theatron, "um lugar onde se $v \hat{e}$. Deste modo e antes de mais, o teatro cenoplástico procura a criação de visões inesquecíveis, por mais fantásticas ou devastadoras que possam aparecer aos olhos do espectador. No teatro cenoplástico, o ator é um elemento entre outros no contexto dos recursos específicos que integram a linguagem da cena.

Perspectivo dois patronos míticos para o teatro cenoplástico: Apolo, deus da luz e da arquitetura, mestre das musas, mas igualmente inspirador não racional do sonho premonitório; e - adotando uma sugestão que me foi feita por Maria Katzenbach - Afrodite, corpórea deusa da beleza, da sedução e da sensualidade. Fontes exponenciais para o teatro cenoplástico são Adolphe Appia, o teórico essencialista da luz e do espaço "vivo" no espetáculo teatral, verbal e musical; Gordon Craig, que sustentou uma autonomia estética para o teatro, ou seja, o teatro como forma de representação artística dotada de leis e vida próprias; e mais recentemente Robert Wilson, cuja estética cênica foi entendi- 
da por Stefan Brecht como "um teatro de visões", ou ainda as realizaçôes cênicas de um Romeo Castellucci.

Em termos de analogia antropomórfica, o teatro cenoplástico é o teatro como corpo, enquanto lugar de sedução no qual o teatro nasce e evolui para a vida que lhe é própria.

Deste modo, o teatro cenoplástico corresponde à função sensação (sensation function) na tipologia junguiana.

(4) Teatro Arquetípico: o teatro destinado à disseminação de materiais arquetípicos, baseado no pressuposto de que as imagens e os enredos míticos possuem o poder de estabelecer conexões comunicantes entre o inconsciente individual e o inconsciente coletivo, quer entre os espectadores, quer entre os próprios atores e demais intérpretes fazedores da cena. Enquanto forma teatral, as suas raízes remontam ao drama grego antigo. Se bem que os motivos de natureza arquetípica estejam, como é óbvio, presentes em todas as formas teatrais, o teatro arquetípico distingue-se das restantes formas por reclamar para o teatro uma função transformativa, psico-activante; ele não visa exclusivamente proporcionar prazer emotivo, indagação cognitiva, e/ou maravilhamento sensitivo, junto do espectador, mas, acima de tudo, despertar nele uma centelha interior, para além da consciência racional, através da imaginação simbólica. O teatro arquetípico é animado por preocupaçóes existenciais, espirituais e antropológicas, em suma; e tanto pode emanar da experiência performativa do ator, enquanto significador cênico da condição humana, como eclodir de um texto escrito que é representado.

O patrono mítico do teatro arquetípico é Hermes, o mensageiro que liga os vários mundos, o decifrador de enigmas, também o embusteiro, mas, mais crucialmente, o deus alado do conhecimento interior, e o psicopompo, isto é, aquele que guia as almas entre a vida e a morte.

Fontes teóricas para o teatro arquetípico são encontradas: nas reflexões soltas de escritores dramáticos simbolistas, como sejam
Edouard Schuré, Maurice Maeterlinck, W. B. Yeats, António Patrício, e Fernando Pessoa; em Antonin Artaud, cuja contribuição seminal está no propósito visionário de revalorizar a imaginação mítica no contexto do teatro novecentista; em Jung, que contribuiu, entre vários outros aspectos, com a teoria dos arquétipos e com o conceito de inconsciente coletivo; em Jerzy Grotowski, o enunciador da noção de "teatro pobre", bem como em Peter Brook que classificou o teatro deste último, conjuntamente com a dramaturgia de Beckett (em O Espaço Vazio, 1968), sob a classificação de "holy theatre" (teatro sagrado).

Em termos antropomórficos, o teatro arquetípico é o teatro como espirito, a demanda por um conhecimento não-mediado pelo pensamento racional, mas que é experienciado diretamente pela consciência.

Deste modo, o teatro arquetípico opera no modo da função intuição (intuitive function) no contexto da tipologia de Jung.

Num sentido geral, o teatro gnóstico pode ser considerado como uma subcategoria ou variante do teatro arquetípico, mas com efeito, a um nível mais profundo, pode representar o equivalente dramatúrgico daquilo que Jung, em termos psicológicos, designou por função transcendente. O que pretendo dizer com isto é que, embora o teatro gnóstico emerja de uma modalidade teatral arquetípica e partilhe os objetivos dessa mesma modalidade, ele incorpora e mobiliza um amplo conjunto de elementos expressivos radicados em todas as diversas formas de expressão teatral enunciadas; agregando todas elas, deliberadamente, num modo a provocar a expansão da consciência por ação da imaginação ativa (numa analogia com o processo psicológico que Jung nomeia por função transcendente). Assim sendo, o teatro gnóstico reconhece que o seu horizonte de concretização estética apenas pode ser alcançado através de uma equilibração interativa das quatro dimensões antrópicas de alma, mente, corpo e espírito, e, assim sendo, pela união correspondente 
das quatro funções psicológicas junguianas: sentimento, razão, sensação e intuição. $\mathrm{O}$ teatro gnóstico, no seu convite a uma expansão libertadora da psique de cada espectador, agrega e funde as funçôes que cada uma das quatro formas de expressão teatral enunciadas pratica como prioridade sua: a emoção e/ou a diversão lúdica (da catarse cômica) produzidas pelo teatro dramático; a cognição e o prazer reflexivo estimulados pelo teatro crítico; a fascinação e o apelo sensorial promovidos pelo teatro cenoplástico; a intuição e a experiência de conexão ao inconsciente, individual e coletivo, proporcionadas pelo teatro arquetípico.

A partir deste entendimento mitocrítico do teatro gnóstico (que o leitor é livre de considerar como um simples jogo de especulação imaginativa), é possível, por exemplo, identificar um conjunto de obras no âmbito da dramaturgia ocidental contendo elementos teatrais gnósticos e susceptíveis, por esse motivo, de se verem inseridas na genealogia do teatro gnóstico. Exemplos possíveis de criaçôes dramáticas com tais características, que apenas nomeio aqui sem as explorar em termos hermenêuticos: As Bacantes, de Eurípides; A Tempestade, de Shakespeare; A Vida é Sonho, de Calderón; Quando nós despertarmos de entre os mortos, de Ibsen; A Gaivota, de Tchekov; Um Sonho, de Strindberg; e Dias Felizes, de Beckett, para citar apenas alguns casos emblemáticos de circulação universal.

Como forma de arte, o teatro gnóstico busca potenciar na linguagem estética aquilo que esta integra de terapia simbólica para a psique individual e coletiva; um esforço amplificador que reverbera na ideia de catarse (incluindo a catarse do riso, como ela é patente na tragicomédia beckettiana), palavra de uso muito difundido em dramaturgia - noção esta, porém, tão vagamente definida por Aristóteles, que a introduziu em teoria do teatro, dando origem a um interminável mas vívido deba- te relativamente ao que o processo catártico envolve exatamente.

Artaud (cuja filiação no pensamento gnóstico foi analisada por Susan Sontag no ensaio que a ele dedica em 1973, filiação esta depois escrutinada por Jane Goodall em Artaud and the Gnostic Drama, 1994) incitava a um renascimento da antiga prática da catarse dramática que ele acreditava passível de re-atualização, inspirado nos antigos Mistérios de Elêusis (que exerceram sobre ele um imenso fascínio, tal como sobre outros autores desde Platão a Fernando Pessoa e a Grotowski). Nestes rituais iniciáticos, de experiência transformativa, a imaginação simbólica seria activada em cada participante, individualmente considerado, através da gnose íntima de uma forma de teatralização, fundamentalmente diferente, segundo é lícito supor, daquela que estava presente nos festivais públicos de Atenas em honra de Dioniso.

Graças a uma reconstituição ritual do núcleo mítico de Deméter-Perséfone-Hades, os participantes em Elêusis seriam induzidos (não se sabe se com o auxílio de substância alucinogénea) a um despertar congenial ao processo de auto-descoberta. Movidos pelo visionarismo mitopoético de Artaud, podemos imaginar que os Mistérios de Elêusis seriam remotos antecedentes culturais e ritualísticos do teatro gnóstico. Porém, ao mesmo tempo, o pressuposto de não haver propriamente espectadores, mas sim participantes de pleno direito (de ambos os sexos e oriundos das várias condiçôes sociais), no ato de realização cênico, faz dos Mistérios de Elêusis, antes de mais, um surpreendente ascendente antropológico do que visamos hoje por teatro comunitário, com a forte intenção inclusiva face ao lugar do outro e energizador dele, quebrando a linha que separa cena e plateia. Mas esta aproximação, onde a contemporânea interatividade de Teatro e Comunidade se revela já manifestada na cena ancestral e mistérica de Elêusis, terá de ser motivo para outra viagem mitocrítica. 


\section{Referências bibliográficas}

ARISTÓTELES, Poética. Trad. de Eudoro de Sousa. Lisboa: Imprensa Nacional - Casa da Moeda, 1986.

ARTAUD, Antonin [1938]. O Teatro e o seu duplo. Trad. de Fiama Hasse Pais Brandão. 2o edição. Lisboa: Fenda, 1989.

BACHELARD, Gaston [1942]. A água e os sonhos. Trad. de Antonio de Padua Danesi. São Paulo: Martins Fontes, 1989.

GIL, José. Portugal hoje, o medo de existir. Lisboa: Relógio d’Água, 2004.

GOODALL, Jane. Artaud and the Gnostic drama. Oxford: Oxford University Press, 1994.

JONAS, Hans [1958]. The Gnostic religion. The message of the alien God and the beginnings of Christianity. London: Routledge, 1992.

JUNG, C. G. [1997], On Active Imagination. Key readings selected and introduced by Joan Chodorow. London and New York: Routledge, 2009.

[1921]. Tipos Psicológicos. Trad. de Lúcia Mathilde Endlich Orth. Petrópolis: Vozes, 1991.

MERCADO, António. "Rosa’s gnostic theatre in context". In ROSA, Armando Nascimento [2006]. Mary of Magdala. A gnostic fable. Transl. by Alex Ladd. Introduction by Veronica Goodchild and essays by Bradley TePaske, Susan Rowland, Sally Porterfield, Nancy Qualls Corbett, Rosamonde Miller, and António Mercado. New Orleans: Spring Journal Books, 2010.

ROSA, Armando Nascimento [2003]. An Oedipus - The untold story. A ghostly mythodrama in one act. Transl. by Luis Toledo, revised by Michael Mendis. Foreword by Susan Rowland and essays by Marvin Carlson and Christine Downing. New Orleans: Spring Journal Books, 2006.

. Antígona Gelada. Prefácio de Maria do Céu Fialho. Coimbra: Fluir Perene/Centro de Estudos Clássicos e Humanísticos da Universidade de Coimbra, 2008.

As máscaras nigromantes. Uma leitura do teatro escrito de António Patrício. Lisboa: Assírio \& Alvim, 2003.

. Audição - Com Daisy ao vivo no Odre Marítimo. Évora: Casa do Sul, 2002.

. A última lição de Hipátia seguido de O túnel dos ratos. Porto: Campo das Letras, 2004.

. Lianor no país sem pilhas. Uma peça teatral infanto-juvenil. Porto: Campo das Letras, 2001.

. Maria de Magdala. Fábula gnóstica. Lisboa: Parceria A. M. Pereira, 2005.

. Não és Beckett, não és nada. Uma paródia beckettiana. Lisboa: Apenas Livros, 2009.

. Nória e Prometeu. Palavras do Fogo. Mitodrama paródico em sete cenas. Lisboa: edição online de 2004, disponível em http://www.triplov.org/teatro/armando_nascimento_rosa/ noria_e_prometeu/index.htm

O Eunuco de Inês de Castro. Teatro no país dos mortos. Prefácio de Patrícia da Silva Cardoso. Évora: Casa do Sul, 2006.

. Um Édipo - O drama ocultado. Mitodrama fantasmático em um ato. Évora: Casa do Sul, 2003. 
. Visita na prisão ou O último sermão de António Vieira. Fiç̧ão histórico-cénica. Lisboa: Assírio \& Alvim, 2009.

SONTAG, Susan [1972-1980]. Sob o signo de Saturno. Trad. de Ana Maria Capovilla e Albino Poli Jr. Porto Alegre/São Paulo: 1986.

STEINER, George [1996]. Paixão Intacta. Ensaios 1978-1995. Trad. de Margarida Periquito e Victor Antunes. Lisboa: Relógio d’Água, 2003.

RESUMO: Notas para um teatro mitocritico é um ensaio em três partes com os seguintes títulos e conteúdos: 1) A psique é mitodramática; o autor avalia aqui a relevância de uma abordagem mitocrítica no que respeita ao entendimento do lugar da arte dramática, no contexto das expressōes literárias e culturais, enquanto discurso criativo onde se pode descortinar uma fusão entre poesia e filosofia. De Platão a Aristóteles, até Freud, Jung e Bachelard, uma diversidade de referências se apresentam no sentido de sustentar a importância de uma perspectiva mitocrítica em relação ao teatro e à conexão deste com a imaginação simbólica. 2) Uma vocação mitocrítica; o autor convida o leitor a familiarizar-se com o seu percurso criativo pessoal, enquanto dramaturgo (e teórico) no quadro do teatro português contemporâneo (a sua primeira peça data de 1988), mostrando como a visão mitocrítica pode ser a chave para aceder aos seus trabalhos escritos para a cena. 3) O que é teatro gnóstico: ensaiar uma tipologia mitocrítica; o autor tenta identificar o que significa para si o conceito de teatro gnóstico, uma vez que dele faz uso para designar a sua dramaturgia. Sob a influência da psicologia junguiana, uma hermenêutica mitocrítica define quatro diferentes modos de expressão teatral que estão comummente misturadas nas práticas teatrais: teatro dramático; teatro crítico; teatro cenoplástico; e teatro arquetípico. Uma breve caracterização de cada uma destas categorias é explicitada, bem como uma possível interpretação de como o teatro gnóstico pode ser entendido em relação a elas.

PALAVRAS-CHAVE: Mitocrítica - teatro/teoria - psique e escrita para a cena - dramaturgia portuguesa contemporânea - imaginação simbólica - teatro gnóstico - teatro dramático - teatro crítico - teatro cenoplástico - teatro arquetípico. 